\title{
HOW SME UNIQUENESS AFFECTS CAPITAL STRUCTURE: EVIDENCE FROM A 1994-1998 SPANISH DATA PANEL*
}

\author{
Francisco Sogorb
}

WP-EC 2002-18

Correspondence to: Francisco Sogorb Mira, Universidad Cardenal Herrera CEU, Facultad de Ciencias Sociales y Jurídicas, Campus de Elche, Comissari, 103203 Elche (Alicante), Tel.: 9654264 86, Fax: 9654595 61, E-mails: fsogorb@uch.ceu.es, sogor.el@cue.es.

Editor: Instituto Valenciano de Investigaciones Económicas, S.A.

Primera Edición Julio 2002

Depósito Legal: V-2748-2002

IVIE working papers offer in advance the results of economic research under way in order to encourage a discussion process before sending them to scientific journals for their final publication.

\footnotetext{
* The author would like to express his gratitude to J. Carlos Gómez Sala for his inestimable help and encouragement and to Manuel Arellano, José López Gracia and Javier Suárez for their invaluable comments on earlier drafts. The author would also like to thank the participants at the $8^{\text {th }}$ Annual Conference of the Multinational Finance Society (Italy, June 2001) for their helpful comments to a preliminary version of this paper, and the insightful suggestions by an anonymous referee. Any errors or omissions are the sole responsibility of the author.
} 


\title{
HOW SME UNIQUENESS AFFECTS CAPITAL STRUCTURE: EVIDENCE FROM A 1994-1998 SPANISH DATA PANEL
}

\section{Francisco Sogorb}

\begin{abstract}
The principal aim of this paper is to test how firm characteristics affect Small and Medium Enterprise (SME) capital structure. We carry out an empirical analysis over a panel data of 6482 non-financial Spanish SMEs along the five-year period 1994-1998, modelling the leverage ratio as a function of firm specific attributes hypothesized by capital structure theory. Our results suggest that non-debt tax shields and profitability are both negatively related to SME leverage, while size, growth options and asset structure influence positively on SME capital structure; they also confirm a maturity matching behaviour in this firm group.

Keywords: Financing, Capital Structure, Trade - Off Theory, Pecking Order Theory, SME, Panel Data.
\end{abstract}

JEL Classification: C23, G32, G33.

\section{RESUMEN}

El principal objetivo de este trabajo reside en estudiar cómo determinadas características empresariales afectan a la estructura de capital de la Pequeña y Mediana Empresa (PYME). Para lograr este objetivo, se lleva a cabo un análisis empírico sobre un panel de 6482 PYMEs no financieras españolas a lo largo del lustro 1994-1998. El ratio de endeudamiento se contempla como una función de aquellos atributos específicos de las empresas que han sido identificados por la teoría de la estructura de capital. Los resultados obtenidos sugieren que, tanto los escudos fiscales alternativos a la deuda como la rentabilidad empresarial, se encuentran negativamente relacionados con el endeudamiento de las PYMEs, mientras que el tamaño, las oportunidades de crecimiento y la estructura de los activos influyen de forma positiva en la estructura de capital de las PYMEs. Estos resultados también confirman un comportamiento tendente a la conciliación de vencimientos de activos y pasivos en este grupo empresarial.

Palabras clave: Financiación, estructura de capital, "Trade-off Theory", "Pecking Order Theory", PYME, Panel de Datos. 


\section{Introduction}

It is generally accepted that small and medium enterprises, hereinafter SMEs, represent a vast portion of the firm tissue of almost every developed country. In this respect, the Sixth Report about European companies carried out by the European Commission (2000), reveals that the total number of firms existing in the European Union in 1998 mounted up to 19,370,000, from which $99.8 \%$ were considered SMEs. Moreover, these SMEs provided approximately around $66 \%$ of European employment and $65 \%$ of European companies' turnover. The records for Spain are in line with the European ones: there were 2,591,318 SMEs (99.8\% of total firms) in 2000, carrying out $79.8 \%$ of Spanish employment and $62 \%$ of Spanish firm's total sales (DGPYME, 2002). All these figures show the great importance of this category of firms, but not always receiving the joust attention that they really deserve. In words of Zingales (2000, p. 1629): "Empirically, the emphasis on large companies has led us to ignore (or study less than necessary) the rest of the universe: the young and small firms, who do not have access to public markets".

One of the areas of financial economy that has worried much to academicians and professionals is debt policy decisions in companies. Although there are many previous empirical studies about financing decisions of large and listed companies ${ }^{1}$, the scientific community has only started to pay attention to the small firm sector much more recently.

In spite of this, we now have available a considerable number of empirical works worldwide like Van der Wijst (1989), Walker (1989a,b), Holmes and Kent (1991), Norton (1991), Van der Wijst and Thurik (1993), Chittenden et al. (1996), Hamilton and Fox (1998), Jordan et al. (1998), Michaelas et al. (1999), Wagenvoort and Hurst (1999) and Hall et al. (2000), and also for the Spanish context like Ocaña et al. (1994), Maroto (1996), Boedo and Calvo (1997), López and Romero (1997), Selva y Giner (1999), López and Aybar (2000), Aybar et al. (2001), Cardone and Cazorla (2001) and Melle (2001).

\footnotetext{
${ }^{1}$ For example, Bradley et al. (1984), Friend and Hasbrouck (1988), Titman and Wessels (1988), Mato (1990), Barclay et al. (1995), Rajan and Zingales (1995), Graham (1996), Saá-Requejo (1996), Estrada y Vallés (1998), Shyam - Sunder and Myers (1999),Hovakimian et al. (2001), Miguel and Pindado (2001) and Fama and French (2002).
} 
Following this line of research, we aim to obtain the main determinants of debt policy decisions in small firms. In doing so, we will explain how firm characteristics affect Small and Medium Enterprise (SME) capital structure. To achieve this goal we use a panel data methodology controlling for individual heterogeneity, economic activity and time effects, and a more complete and bigger sample than the foregoing studies.

The structure of the remainder of the paper is as follows. Section 2 studies how the existing capital structure theories can be used to explain the financing decisions in the small business sector and at the same time we present the empirical hypotheses extracted from the theoretical background that will be tested over a Spanish small and medium enterprise sample. Section 3 explains in detail all the variables used in the study; besides it describes how we have constructed the firm sample. The model employed as well as the econometric techniques that we have applied, are discussed in section 4. Also in this section we show the empirical results of the study with their implications. Finally, we conclude in section 5 where we also include some proposals for the future line of research in this area.

\section{Theoretical discussion and empirical hypotheses}

The seminal work of Modigliani and Miller (1958) set up the basis for the development of a theoretical body around the firm capital structure issue. Its main proposition establishes that the valuation of a company will be independent from its financial structure. As this conclusion is absolutely true under the assumptions Modigliani and Miller (1958) took into account ${ }^{2}$, the enlargement of the theory onwards has been produced relaxing these fundamental assumptions, also with the aim of approximating the theory to the firm reality. From this point of view, we can categorize capital structure theory under different stances, depending on which economic aspect and firm characteristic we focus on.

The conventional analysis of capital structure states that firms determine their leverage level trading off the benefits against the shortcomings that provides debt employment (Scott, 1976; Bradley et al, 1984). Under this line of reasoning, emerges

\footnotetext{
${ }^{2}$ Namely, perfect capital markets, no taxes, and absence of agency and transactions costs.
} 
the so-called Trade-Off Theory (TOT), which includes fiscal, financial distress and interest conflicts issues.

Concerning the fiscal approach of the TOT, Modigliani and Miller corrected their original paper in 1963 concluding that firms would prefer debt to other financing resources due to the tax deductibility of interest payments. Therefore, our first TOT hypothesis will be: "The effective tax rate should be positively related with debt" (H1).

Some authors like Pettit and Singer (1985) have pointed out that this fiscal approach can not be applied into the small firm context, because SMEs are less likely to be profitable and therefore to use debt in order to get tax shields. Following this line of reasoning the foregoing hypothesis could be established as "there should not exist any relation between debt and taxes in SMEs",3 (H1bis).

On the other hand, DeAngelo and Masulis (1980) show that there are other alternative tax shields such as depreciation, research and development expenses, investment deductions, etc., that could substitute the fiscal role of debt. Therefore, our second fiscal approach hypothesis will be: "Non-debt tax shields ought to be negatively related to leverage" $(\mathrm{H} 2)$.

From a financial distress perspective, Warner (1977), Ang et al. (1982) and Pettit and Singer (1985) state that larger firms tend to be more diversified and fail less often, so size can be an inverse proxy for the probability of bankruptcy ${ }^{4}$. Likewise, small companies usually have bigger bankruptcy costs in relative terms. Under these assertions, we can construct our third Trade-Off Theory hypothesis in the following manner: "Firm size should be positively related to debt level" (H3).

Agency theory investigates the conflicts of interests between the various financial stakeholders of the firm. Basically, this theory considers the conflicts of interest brought about, on the one hand, between shareholders and debt holders and, on the other hand, between shareholders and managers. SMEs are not likely to suffer from this second problem due to the fact that their property identifies almost exactly with their management and thereby there will only be a unique financial objective for these two groups. Notwithstanding, the agency conflict between shareholder-owners and

\footnotetext{
${ }^{3}$ Graham (1996) found a positive relation between firm size and taxes, which implies that SMEs have lower tax rates.

${ }^{4}$ Note however, as Rajan and Zingales (1995) state, that size may also be a proxy for the information outside investors have, which should increase their preference for equity relative to debt.
} 
financiers may be particularly severe for small companies, increasing both the moral hazard and adverse selection problems (Van der Wijst, 1989; Ang, 1992).

Following Myers (1977), the under-investment problem becomes more intense in companies with more growth opportunities, and this fact will take creditors to reduce their supply of funds to this type of firms. One of the possible solutions to mitigate this problem could be the employment of short-term debt by the firm. In theory, and according to Myers' assertion, there should be a negative relationship between debt and growth opportunities; however some authors like Michaelas et al. (1999) have propounded a positive relationship between these two variables because SMEs mainly use short term debt financing. In line with this last proposition, our fourth TOT hypothesis is: "Growth opportunities ought to be positively related with firm leverage" (H4). Nevertheless, this hypothesis could be decomposed into: (i) "Long term debt should be negatively related to growth opportunities" (H4-a), and (ii) "Short term debt should have a positive relationship with growth opportunities 5 ", (H4-b).

The restriction of maturity length in credit offered by lenders may explain partially debt structure in SMEs. In this sense, small firms may use less long-term debt, but probably more short-term debt, than larger firms. This may suggest, following Bevan and Danbolt (2000b) and Hall et al. (2000), these next relationships in form of our fifth TOT double hypothesis: (i) "Long term debt should be positively related to firm size" (H5-a), and (ii) "Short term debt should have a negative relationship with firm size" (H5-b).

The existence of debt agency costs like risk shifting, and potential problems of adverse selection and moral hazard, may induce creditors to require guarantees to their lending, materialized in collateral assets (Myers, 1977; Scott, 1977, Harris and Raviv, 1990). This kind of assets will retain value in case of a potential liquidation of the firm, and could be sold in the market to face the firm's payment commitments. We formulate our sixth and last Trade-Off theory hypothesis in the following terms: "The firm leverage ratio should relate positively to asset tangibility" (H6).

Myer's (1977) debt overhang problem deals with the fact that firm managers may pass up profitable investments $(\mathrm{NPV}>0)$ if these projects were to benefit

\footnotetext{
${ }^{5}$ According to Barclay and Smith (1999), when firms with high growth opportunities use debt financing, they will prefer short term debt or debt with few restrictive covenants instead of long term debt, in order to maintain their financial flexibility.
} 
exclusively creditors. In fact, company owners will try to take up those investments that generate short-term cash flows (managers myopia); however financiers will only be willing to lend resources at a larger kind of seniority, as for example short-term debt. According to this view and to the maturity matching principle from Brealey and Myers (2000), the preceding hypothesis H6 could be enlarged in the following sense: "If firms aim to match maturities of assets and liabilities, we should observe a positive relationship between fixed assets ratio and long term debt ratio, while it would be negative if leverage ratio were short term" (H6-a).

Last but not least, if we consider the existence of informational asymmetries between investors and managers, two additional capital structure theories appear: the Signaling Theory and the Pecking Order Theory (POT). The former theory is of almost no use for the small firm sector as SMEs are not usually listed in stock exchange markets, and therefore their managers do not intend to signal something to the market and investors, while adopting their financing decisions. On the contrary, the latter theory could be very useful for our purposes.

Myers (1984) and Myers and Majluf (1984) argue that it exists a hierarchy in the financing funds of companies. Due to informational asymmetries, firms will prefer internal to external capital sources. This suggests that high profitable companies will tend to finance investments with retained earnings rather than using debt. It is worthy stressing that this way of firm financing could easily be applied to SMEs through the following reasoning: SMEs managers, that are usually at the same time shareholders of this companies, do not like to lose their property and control over these firms (Holmes and Kent, 1991; Hamilton and Fox, 1998), and therefore the acceptance of new shareholders will be almost insignificant, preferring internal financing to external resources to finance firm activity ${ }^{6}$. In case SMEs needed external funds, they would choose debt that does not reduce managers' operability, that is, short-term debt that is not likely to include restrictive covenants. Under this last theoretical stance, we propose these two hypotheses: (i) "There should be a negative relation between leverage and firm profitability" (H7), and (ii) "SMEs employ predominantly short term debt as debt financing” (H8).

\footnotetext{
${ }^{6}$ In his revised version of the pecking order theory applied to SMEs, Ang (1991) establishes that the second financing resource for SMEs, after retained profits, will be funds supplied by the present firm shareholders.
} 


\section{Description of data source and variables}

\subsection{Data source}

A key question in all SMEs literature is the definition of what is really considered as a small business. Every author, in most of the cases, has defined this sort of business quite differently. For instance, Van der Wijst (1989) considers small and medium-sized business as privately held firms with 1-9 and 10-99 people employed, respectively; Ocaña et al. (1994) investigate firms with less than 50 employees (small) and firms with employees between 50 and 200 (medium); Boedo and Calvo (1997) work with firms that have a 2.4-3.6 million € turnover; Jordan et al (1998) define SMEs as firms with less than 100 employees and less than 15 million $€$ turnover; Michaelas et al. (1999) consider small independent private limited companies with less than 200 employees; López and Aybar (2000) analyse companies with sales below 15 million $€$; and Aybar et al. (2001) contemplate firms with sales under 2.4 million $€$ (small) and firms with sales between 2.4 million $€$ and 15 million $€$ (medium). This fact suggests that there is not a general consensus over what a small business is.

Instead of taking any of the previous criterions, we have adopted the European Commission SME definition $^{7}$

- companies with less than 250 employees,

- sales below 40 millions $€$,

- $\quad$ total assets under 27 millions $€$,

- independent privately held ${ }^{8}$.

The sample of SMEs considered in our study has been extracted from SABE (Sistema de Análisis de Balances Españoles), which is a database that contains economic and financial information with up to eight years of history over more than

\footnotetext{
${ }^{7}$ Recommendation 96/280/EC, April 3, 1996.

${ }^{8}$ These firms can not belong to a big company or to a group of companies.
} 
190,000 Spanish firms ${ }^{9}$. SABE is managed by Informa, S.A. and is supposed to include more than $95 \%$ of the companies from the 17 Spanish autonomous communities that deposit their financial statements at the Mercantile Registry Offices, with more than $601,000 €$ turnover or more than 10 employees. Their sources of information are the Mercantile Registry Offices, Official Bulletins (like BORME) and Chambers of Commerce, among others.

Specifically, we have selected those firms from this database that meet the following requirements: (i) less than 250 employees; (ii) less than 40 million $€$ turnover; (iii) less than 27 million $€$ total assets; (iv) positive equity resources (shareholders' equity) and also positive net income over the whole period of study; and (v) not included in a bankruptcy process. The data set has been restricted to observations that embody all the essential variables available, and also these variables have a complete record over the period of examination.

The definitive number of firms that makes up our sample amounts to 6482 , for which we have accounting data for the five year period time $1994-1998^{10}$, resulting in a 32410 observations balanced panel data. It should be noted that our firm data panel is much more complete that the ones that have been used in previous studies, and enjoys a greater number of observations ${ }^{11}$.

The vast majority of empirical studies about firm capital structure usually consider companies from mixed industries. However, almost all of them regularly exclude from their analysis firms belonging to the insurance and financial industry because of their specific financial behavior and particular nature ${ }^{12}$. Moreover, if we

\footnotetext{
${ }^{9}$ Nowadays, this database is called SABI (Sistema de Análisis de Balances Ibéricos) as it has extended its firm coverage in 2002 ( $32^{\text {nd }}$ version) including about 18,000 Portuguese firms.

${ }^{10}$ As the SABE database was created in 1992, its firsts two years of performance are not very complete in terms of firm data, so we preferred to begin our study from 1994 onwards in order to use a greater quantity and better quality information.

${ }^{11}$ For instance, López and Aybar (2000) consider only 445 SMEs with 1 year (1995) of observations and although Michaelas et al. (1999) analyze about 3500 SMEs over a 10 year period, they do not have at their disposal firm information for the whole period of time, taking into account less than 2000 companies for some of the years of study.

12 See, for example, Rajan and Zingales (1995), Graham (1996), Shyam - Sunder and Myers (1999), Bevan and Danbolt (2000a), Bevan and Danbolt (2000b), Hovakimian et al. (2001), Miguel and Pindado (2001), and Fama and French (2002).
} 
attempt to analyze the financing decision in SME, it would be nonsense to include the cited industries in our study.

Firm distribution by industries of our sample and the specific weight of each firm sector over the total sample is shown in table 1.

Table 1: Firm distribution by industries and specific weights

\begin{tabular}{lcr}
\hline Industry & Number of firms & \% of total firms \\
\hline Agriculture, forestry and mining & 139 & 2.14 \\
Manufacturing & 2053 & 31.67 \\
Construction & 667 & 10.29 \\
Wholesale and retail trade & 2630 & 40.57 \\
Hotels and restaurants & 153 & 2.36 \\
Transport and communications & 237 & 3.66 \\
Business services & 445 & 6.87 \\
Education, health, social work and others & 158 & 2.43 \\
\hline TOTAL & $\mathbf{6 4 8 2}$ & $\mathbf{1 0 0}$ \\
\hline
\end{tabular}

As can be observed, both manufacturing and wholesale and retail trade prevail over the rest of industries.

\subsection{Variables}

In each of the empirical hypotheses that we formulated in section 2 an economic or financial aspect of the firm was taken into account and the question that arises now is how to measure these attributes. Capital structure theory does not specify clearly this issue, which has taken some researchers like Titman and Wessels (1988) or Harris and Raviv (1991) to conclude that the choice of appropriate both dependent and explanatory variables is potentially controversial. Nonetheless, previous empirical work can help us to define objectively the proxy variables needed to take on our study.

The variable that we intend to explain is SME capital structure, which we measure by total debt ratio (TDR): $\frac{\text { Total Debt }}{\text { Total Assets }}$. But as argued by Van de Wijst and Thurik (1993), Chittenden et al. (1996), Barclay and Smith (1999) and Bevan and 
Danbolt (2000a), any analysis of leverage determinants based only on total liabilities may screen the important differences between long-term and short-term debt. Consequently, in order to shed some light over this question and to get a better understanding of capital structure and its determinants, we also consider the following two measures of leverage: (i) Long term debt ratio (LDR) $\frac{\text { Long-Term Debt }}{\text { Total Assets }}$, and (ii) Short term debt ratio (SDR): $\frac{\text { Short-Term Debt }}{\text { Total Assets }}$

As far as explanatory variables is concerned, we have selected several proxies that have been most used in the empirical literature.

- Effective Tax Rate (ETR): $\frac{\text { Taxes }}{\text { EAIBT+Depreciation }}$, where EAIBT denotes Earnings after interest and before taxes, and Depreciation is taken as a flow variable.

- Non-Debt Tax Shields (NDTS): $\frac{\text { Depreciation }}{\text { Total Assets }}$ where Depreciation is taken as a flow variable.

- Growth Opportunities (GO): $\frac{\text { Intangible Assets }}{\text { Total Assets }}$ investment rate of the previous period.

- Asset Structure (AS): $\frac{\text { Tangible Assets }}{\text { Total Assets }}$

- $\quad$ Size (S): natural logarithm of total assets.

- Profitability $(\mathrm{P}): \mathrm{ROA}=\frac{\mathrm{EBIT}}{\text { Total Assets }}$, where EBIT denotes Earnings before Interest and Taxes.

A preliminary study of our data sample provides us with the main descriptive statistics of both dependent and explanatory variables that we collect in table 2 .

A quick review to table 2 displays several matters. In first place, total liabilities on average amount to about $61 \%$ of total assets value. If we split total liabilities into fixed liabilities (repayable in more than one year) and current liabilities (repayable in less than one year), the figures $9 \%$ and $52 \%$ respectively, show that debt financing for SMEs in our sample corresponds mainly to a short-term nature, exactly $85 \%$. Note, that, initially, this fact is consistent with our empirical hypothesis H8. 
Table 2: Descriptive statistics of dependent and explanatory variables

\begin{tabular}{lccccc}
\hline \hline Variable & Obs. & Mean & Std. Deviation & Minimum & Maximum \\
\hline TDR & 32410 & 0.6141 & 0.2286 & 0 & 0.9988 \\
LDR & 32410 & 0.0895 & 0.1337 & 0 & 0.9665 \\
SDR & 32410 & 0.5245 & 0.2293 & 0 & 0.9988 \\
ETR & 32410 & 0.1831 & 0.1068 & 0 & 0.8232 \\
NDTS & 32410 & 0.0353 & 0.0364 & 0 & 1.2236 \\
GO & 32410 & 0.0347 & 0.0722 & 0 & 0.9386 \\
AS & 32410 & 0.4404 & 0.2392 & 0 & 1 \\
S & 32410 & 13.8989 & 1.1848 & 8.1682 & 17.1111 \\
P & 32410 & 0.0962 & 0.0884 & -1.0258 & 3.5468 \\
\hline \hline
\end{tabular}

TDR: Total Debt Ratio. LDR: Long-Term Debt Ratio. SDR: Short-Term Debt Ratio. ETR: Effective Tax

Rate. NDTS: Non - Debt Tax Shields. GO: Growth Opportunities. AS: Asset Structure. S: Size.

P: Profitability.

The average effective tax rate of Spanish SMEs is about $18 \%$, which is clearly lower than the general tax rate that moves between 30\% and 35\% in Spanish fiscal system, depending basically on the economic situation of companies. With respect to asset structure, we find that intangible assets represent over 3\% of total assets value, whereas fixed assets represent about $44 \%$ of total assets. The mean of the natural logarithm of total assets over the period 1994-1998 indicates that the average size of SMEs was approximately $1,086,965 €$ in terms of assets, ranging from a $3527 €$ minimum value to a $26,993,320 €$ maximum value. As far as profitability is concerned, the average return on assets over the period of study mounts up to almost $10 \%$, finding a great disparity between firms, with a $-103 \%$ minimum value to a $355 \%$ maximum value.

To examine the possible degree of collinearity among variables, we have obtained the correlation matrix of dependent and independent variables that we gather in table 3 . 
Table 3: Correlation Matrix

\begin{tabular}{c|c|c|c|c|c|c|c|c|c} 
& TDR & LDR & SDR & ETR & NDTS & GO & AS & S & P \\
\hline TDR & 1 & & & & & & & & \\
\hline LDR & 0.2868 & 1 & & & & & & & \\
\hline SDR & 0.8295 & -0.2971 & 1 & & & & & & \\
\hline ETR & -0.1834 & -0.2279 & -0.0500 & 1 & & & & & \\
\hline NDTS & -0.1179 & 0.1492 & -0.2945 & -0.3901 & 1 & & & & \\
\hline GO & 0.0970 & 0.2763 & -0.0644 & -0.1539 & 0.2803 & 1 & & & \\
\hline AS & 0.0466 & 0.2497 & -0.0991 & -0.2239 & 0.0986 & -0.1637 & 1 & & \\
\hline S & -0.1326 & 0.0458 & -0.1588 & 0.0927 & -0.0490 & -0.0256 & 0.0278 & 1 & \\
\hline P & -0.1676 & -0.0386 & -0.1445 & 0.2694 & 0.0467 & 0.0341 & -0.1311 & -0.0403 & 1
\end{tabular}

As we observe in table 3 , the correlation coefficients are not sufficiently large to cause collinearity problems in the regressions.

\section{Econometric methodology and empirical results}

The panel character of our data allows us to use a panel data methodology for our empirical research. As Baltagi (1995) states this type of analysis presents clear advantages over cross sectional or time series studies. For instance, it can control for firm heterogeneity, and reduce collinearity among the variables that are contemplated (Arellano and Bover, 1990). Likewise, this technique enables us to eliminate the potential biases in the resulting estimates due to correlation between unobservable individual effects and the explanatory variables included in the study. Our panel data model may be represented as follows:

$$
\mathrm{y}_{\mathrm{it}}=\mathrm{X}_{\mathrm{it}}^{\prime} \cdot \beta+\eta_{\mathrm{i}}+\mathrm{u}_{\mathrm{it}}
$$

where $y_{i t}$ is the dependent variable, $X_{i t}$ is a $6 \times 32410$ vector that contains all the explanatory variables, $\beta$ is also a $6 \times 32410$ vector with the variable coefficients that we pretend to estimate, $\eta_{\mathrm{i}}$ denotes the unobservable individual specific effect that is time- 
invariant ${ }^{13}$, and $\mathrm{u}_{\mathrm{it}}$ is the random error, with i denoting firms (cross-section dimension) ranging from 1 to 6482 and $t$ denoting years (time-series dimension) ranging from 1 to 5.

A critical question in cross section models is to identify whether the unobservable individual effects are fixed or random, that is if these effects are orthogonal or not to the exogenous variables considered. Usually, the individual effects are correlated with the independent variables, and as Mato (1990) asserts, this generates biases in the least squares estimators. Notwithstanding, one of the main advantages of panel data models, as the one we employ in this work, is that they give us the possibility to eliminate the cited biases (Baltagi, 1995).

To verify the character of the individual effects, it is usually employed the Hausman's (1978) specification test over the null hypothesis that the individual effects are not correlated with the independent variables $\left[\mathrm{H}_{0}: \operatorname{Cov}\left(\eta_{\mathrm{i}}, \mathrm{X}_{\mathrm{it}}\right)=0\right]$. If we accept the null hypothesis, the individual effects are supposed to be random and we will have to apply Generalized Least Squares (GLS) to our model with instrumental variable estimators. However, if we find that $\mathrm{H}_{0}$ is false, the individual effects are fixed and the GLS estimator becomes biased and inconsistent. In this latter case we will have to transform our original model, subtracting the average of the variables from it:

$$
\mathrm{y}_{\mathrm{it}}-\overline{\mathrm{y}}_{\mathrm{i}}=\left(\mathrm{X}_{\mathrm{it}}^{\prime}-\overline{\mathrm{X}}_{\mathrm{i}}\right) \cdot \beta+\left(\mathrm{u}_{\mathrm{it}}-\overline{\mathrm{u}}_{\mathrm{i}}\right)^{14} \text {, where } \overline{\mathrm{y}}_{\mathrm{i}}=\frac{\sum_{\mathrm{t}=1}^{\mathrm{T}} \mathrm{y}_{\mathrm{it}}}{\mathrm{T}}, \overline{\mathrm{X}}_{\mathrm{i}}=\frac{\sum_{\mathrm{t}=1}^{\mathrm{T}} \mathrm{X}_{\mathrm{it}}}{\mathrm{T}} \text { and } \overline{\mathrm{u}}_{\mathrm{i}}=\frac{\sum_{\mathrm{i}=1}^{\mathrm{T}} \mathrm{u}_{\mathrm{it}}}{\mathrm{T}}
$$

This new model is called the withingroup transformation, and we can use Ordinary Least Squares (OLS) to estimate its parameters, which will provide unbiased estimators.

The outcome of the Hausman's specification test in our study ${ }^{15}$ enables us to reject the hypothesis regarding the absence of correlation between the individual

\footnotetext{
${ }^{13}$ In our study we could associate to this effect the unobservable entrepreneurial or managerial skills of the firm's executives.

${ }^{14}$ Note that the key question in this transformation is that $\eta_{\mathrm{i}}=\bar{\eta}_{\mathrm{i}}$, and therefore $\left(\eta_{\mathrm{i}}-\bar{\eta}_{\mathrm{i}}\right)=0$.

${ }^{15}$ The test statistics for the model with TDR, LTD and STD as dependent variables are 1873.10, 698.61, and 677.64, respectively. All these statistics are asymptotically $\chi^{2}$ distributed with 6 degrees of freedom, and have a p-value of 0.0000 .
} 
unobservable effects and the explanatory variables and, thereby, the choice should be the fixed effects and the within transformation model. It should be pointed out that some authors, like Michaelas et al. (1999) have based their fixed-random choice upon a more intuitive reasoning, rejecting one of the options only whether the sample was supposed to represent the whole economy of a country. However, there is no economical or econometrical reason to consider a priori one of the cited effects. Therefore, if we do not apply this testing methodology we could lose statistical efficiency in the estimation stage.

Once we carry out the regression analysis, we find the following empirical results that are reported in table 4.

Table 4: Regression results

\begin{tabular}{c|ccc}
\hline & TDR & LTD & STD \\
\hline Constant & $0.053(2.41)^{*}$ & $-0.519(25.62)^{* *}$ & $0.572(22.05)^{* *}$ \\
ETR & $-0.114(13.95)^{* *}$ & $-0.098(13.05)^{* *}$ & $-0.016(1.68)$ \\
NDTS & $-0.681(24.61)^{* *}$ & $-0.252(9.92)^{* *}$ & $-0.429(13.20)^{* *}$ \\
S & $0.044(27.75)^{* *}$ & $0.041(28.63)^{* *}$ & $0.002(1.27)$ \\
GO & $0.135(10.90)^{* *}$ & $0.435(38.30)^{* *}$ & $-0.300(20.63)^{* *}$ \\
AS & $0.022(4.44)^{* *}$ & $0.114(24.59)^{* *}$ & $-0.091(15.42)^{* *}$ \\
P & $-0.154(17.22)^{* *}$ & $-0.034(4.09)^{* * *}$ & $-0.121(11.47)^{* *}$ \\
\hline R-squared & 0.0833 & 0.1097 & 0.0334 \\
F (p-value) & $392.55(0.0000)$ & $532.25(0.0000)$ & $149.10(0.0000)$ \\
Number of obs. & 32410 & 32410 & 32410 \\
\hline
\end{tabular}

Absolute value of $\mathrm{t}$-statistics in parentheses; $*$ denotes statistically significant at $5 \%$ and $* *$ significant at $1 \%$.

A general outlook to the results illustrates that almost all the correlations between variables are highly statistically significant (the exceptions are ETR and S with STD); besides the F joint test underlines the need of considering all the variables from a statistical viewpoint.

The two proxy variables that have to do with the fiscal approach of the TradeOff Theory (TOT) show mixed evidence. On the one hand, the effective tax rate appears to have a significant negative relation with firm leverage, which indicates that $\mathrm{H} 1$ is 
rejected. One of the possible explanations of the sign of this effect could be reverse causation between taxes and the firm leverage variable. In this case, companies with more debt level would pay lesser taxes. But perhaps, alternatively, SMEs managers do not try to reduce their fiscal commitment through debt, because they employ other devices to achieve this goal like the ones included in $\mathrm{H} 2$.

Michaelas et al. (1999) obtain this same sign in the relation, although theirs turn out to be not statistically significant to a 5\% confidence level. Jordan et al (1998) also find a negative relationship, explained by the fact that taxes influence debt only due to the effect over retained earnings.

On the other hand, alternative tax shields seem to be negatively related with debt. This fact provides empirical support for $\mathrm{H} 2$, which is obviously accepted, and shows evidence for the controversial DeAngelo and Masulis (1980) hypothesis in the small firm sector.

As revealed in table 4 , size is positively related to debt, which suggests that this variable determines firm leverage not only for larger firms but also among SMEs. H3 is thus accepted. Regarding the decompositional analysis of debt, we observe positive relationships between size and both long-term debt and short-term debt, although in this latter case not statistically significant. Larger firms seem to employ more debt independently of its expiration, perhaps because they can hold a greater bargaining power towards creditors. Consequently, hypothesis 5 -a is accepted but hypothesis 5-b is rejected $^{16}$.

SMEs with more growth opportunities include more debt in their capital structures, which takes us to accept $\mathrm{H} 4{ }^{17}$. Nevertheless, a significant negative correlation appears between the ratio of intangible assets over total assets and short-term debt, which may evidence the different time nature of this sort of assets and liabilities, taking us to reject $\mathrm{H} 4-\mathrm{a}$ and $\mathrm{H} 4-\mathrm{b}$.

\footnotetext{
${ }^{16}$ Bevan and Danbolt (2000b) get similar results, and they only accept our hypothesis 5-b for bank debt.

${ }^{17}$ Michaelas et al. (1999) and Aybar et al. (2001), obtain a significant positive relationship between growth opportunities and debt, the same as Chittenden et al. (1996) and Jordan et al. (1998), although these latter not statistically significant.
} 
As was hypothesized, we find that asset structure is positively related to firm total leverage and so we accept hypothesis 6. Remember that SMEs are more likely to suffer from moral hazard and adverse selection problems; therefore the collateral value of their assets could help to reduce this sort of problems.

As can be seen from table 4, the relationship between leverage and asset structure changes significantly depending on the type of leverage ratio it is used. Specifically, we find that long-term debt ratio is positively correlated with asset structure, while this correlation becomes negative if we consider short-term debt ratio. The same result is obtained by Van der Wijst (1989), Van der Wijst and Thurik (1993), Chittenden et al. (1996), and Hall et al. (2000).

The asset structure variable measures the ratio of tangible to total assets, made up mainly by fixed assets that tend to be long term in nature. The negative correlation between asset structure and short-term debt ratio means that short-term debt (current liabilities) is used to finance non-fixed assets, consisting basically current assets. These results confirm the so-called maturity matching principle, and take us to accept H6-a.

Finally, the negative coefficient on profitability implies evidence for the Pecking Order Theory, where more profitable SMEs tend to use lesser debt when financing their activity. Hypothesis 7 is accepted and SMEs prefer internal resources to external ones as mode of financing.

\section{Conclusions}

Some researchers have pointed out that financial policy in SMEs can be explained by the most known capital structure theories. In order to shed some light over this question and to get a more thorough understanding of the underlying forces that drive capital structure decisions in the SME sector, in this paper we have tested some empirical hypotheses, based on different financing decision approaches, over a panel of 6482 non financial Spanish SMEs during 1994-1998.

We both confirm some prior findings using an alternative more complete data set and extend the analysis using additional firm characteristics such as non-debt tax shields, and a decompositional analysis of firm leverage. 
In the first place, we find leverage to be significantly negatively related to alternative tax shields like depreciation, which may seem to confirm DeAngelo and Masulis (1980) theory when applied it to SMEs. Contrary to expectations, we observe that taxes are negatively related to debt. Perhaps, this may be due to the fact that higher corporate tax rates would result in lower internal funds as well as higher cost of capital. Hence, fixed capital formation and demand for external funds would decrease, implying an inverse relationship between the level of debt and the effective tax rate.

Secondly, size and asset structure are both positively correlated with firm debt level, as stated by the theory. However, regarding asset structure we obtain a positive correlation with long-term debt level but negative with short-term debt level. This may evidence the maturity matching principle in SMEs, where they try to finance their fixed assets with long term debt, and their current assets with short term debt.

Thirdly, SMEs with more growth options seem to employ more debt, although this relationship becomes negative with short-term debt. This fact may suggest that these kinds of assets are linked to a long-term nature, and thus their financing should match it.

Finally, predictions of Pecking Order Theory seems to explain relatively well debt policy in SMEs, although the underlying justification of this theory in our case may resemble manager's propensity to not losing part of their control in the firm. Put another way, SMEs rely their financing on internal resources instead of turning to outside the firm.

Regarding to future lines of research on SMEs capital structure, the study will improve considering a broader time period analysis in order to elucidate whether capital structure in this sort of companies changes along different economic cycles. Furthermore, taking a dynamical look to the issue and formulating dynamic models of debt policy with instrumental variables could enrich the analysis. 


\section{References}

Ang, J. S., 1991, "Small business uniqueness and the theory of financial management", The Journal of Small Business Finance, 1 (1), 1-13.

Ang, J. S., 1992, "On the theory of finance for privately held firms", The Journal of Small Business Finance, 1 (3), 185-203.

Ang, J. S.; Chua, J. H. and McConnell, J. J., 1982, "The administrative costs of corporate bankruptcy: a note", The Journal of Finance, XXXVII (1), March, 219-226.

Arellano, M. y Bover, O., 1990, "La econometría de datos de panel", Investigaciones Económicas, XIV (1), 3-45.

Aybar Arias, C.; Casino Martínez, A. y López Gracia, J., 2001, "Jerarquía de preferencias y estrategia empresarial en la determinación de la estructura de capital de la pyme: un enfoque con datos de panel", WP - EC 2001 - 06, Instituto Valenciano de Investigaciones Económicas.

Baltagi, B. H., 1995, “Econometric Analysis of Panel Data”, John Wiley \& Sons, New York.

Barclay, M. J.; Smith, C. W. and Watts, R. L., 1995, “The determinants of corporate leverage and dividend policies", Journal of Applied Corporate Finance, 7 (4), winter, 4-19.

Barclay, M. J. and Smith, C. W. Jr., 1999, "The capital structure puzzle: another look at the evidence", Journal of Applied Corporate Finance, 12 (1), spring, 8-20.

Bevan, A. A. and Danbolt, J., 2000a, "Capital structure and its determinants in the United Kingdom-A decompositional analysis", Mimeo, 2000/2, Department of Accounting and Finance, University of Glasgow.

Bevan, A. A. and Danbolt, J., 2000b, "Dynamics in the determinants of capital structure in the UK”, Mimeo, 2000/9, Department of Accounting and Finance, University of Glasgow.

Boedo Vilabella, L. and Calvo Silvosa, A. R., 1997, "Un modelo de síntesis de los factores que determinan la estructura de capital óptima de las PYMES", Revista Europea de Dirección y Economía de la Empresa, 6 (1), 107-124.

Bradley, M.; Jarrell, G. A. and Kim, E. H., 1984, "On the existence of an optimal capital structure: theory and evidence", The Journal of Finance, XXXIX (3), July, 857-878.

Brealey, R. A. and Myers, S. C., 2000, "Principles of corporate finance", $6^{\text {th }}$ edition, McGrawHill.

Cardone Riportella, C. and Cazorla Papis, L., 2001, "New approaches to the analysis of the capital structure of SMEs: empirical evidence from Spanish firms", Working Paper 0110, Business Economics Series 03, January, Universidad Carlos III de Madrid. 
Chittenden, F.; Hall, G. and Hutchinson, P., 1996, "Small firm growth, access to capital markets and financial structure: review of issues and an empirical investigation", Small Business Economics, 8, 59-67.

DeAngelo, H. and Masulis, R. W., 1980, "Optimal capital structure under corporate and personal taxation", Journal of Financial Economics, 8, 3-29.

Dirección General de Política de la Pequeña y Mediana Empresa, 2002, "Las PYME en España 1996/2000”, Colección Panorama Pyme 01, Dirección General de Política de la Pyme, Secretaría de Estado de Economía, de la Energía y de la Pyme, Ministerio de Economía.

Estrada, A. y Vallés, J., 1998, "Investment and financial structure in Spanish manufacturing firms", Investigaciones Económicas, XXII (3), 337-359.

European Observatory for SMEs, 2000, "Sixth Annual Report", Report submitted to Directorate - General XXIII of the Commission of the European Communities.

Fama, E. F. and French, K. R., 2002, "Testing trade - off and pecking order predictions about dividends and debt", The Review of Financial Studies, 15 (1), March, 1-33.

Friend, I. and Hasbrouck, J., 1988, "Determinants of capital structure", In Andy Chen (ed.), Research in Finance, 7, JAI Press Inc., New York, 1-19.

Graham, J. R., 1996, "Debt and the marginal tax rate", Journal of Financial Economics, 41, May, 41-73.

Hall, G.; Hutchinson, P. and Michaelas, N., 2000, "Industry effects on the determinants of unquoted SME's capital structure", International Journal of the Economics of Business, 7 (3), 297-312.

Hamilton, R.T. and Fox, M.A., 1998, "The financing preferences of small firm owners", International Journal of Entrepreneurial Behaviour \& Research, 4 (3), 239-248.

Harris, M. and Raviv, A., 1990, "Capital structure and the informational role of debt", The Journal of Finance, XLV (2), June, 321-349.

Harris, M. and Raviv, A., 1991, "The theory of capital structure", The Journal of Finance, XLVI (1), March, 297-355.

Hausman, J.A., 1978, "Specification tests in econometrics", Econometrica, 46, 1251-1271.

Holmes, S. and Kent, P., 1991, "An empirical analysis of the financial structure of small and large Australian manufacturing enterprises", The Journal of Small Business Finance, 1 (2), 141-154.

Hovakimian, A.; Opler, T. and Titman, S., 2001, "The debt-equity choice", Journal of Financial and Quantitative Analysis, 36 (1), March, 1-24. 
Jordan, J.; Lowe, J. and Taylor, P., 1998, "Strategy and financial policy in UK small firms", Journal of Business Finance \& Accounting, 25 (1) \& (2), January/March, 1-27.

López Gracia, J. and Aybar Arias, C., 2000, "An empirical approach to the financial behaviour of small and medium sized companies", Small Business Economics, 14, pp. 55-63.

López Gracia, J. y Romero Martínez, M., 1997, "Estudio comparado de la estructura financiera de la pyme en la Unión Europea", Actualidad Financiera, año II (11), Noviembre, 4959.

Maroto Acín, J. A., 1996, "Estructura financiera y crecimiento de las Pymes", Economía Industrial, 310, IV, 29-40.

Mato, G., 1990, "Un análisis econométrico de la política de endeudamiento de las empresas con datos de panel”, Investigaciones Económicas, XIV (1), 63-83.

Melle Hernández, M., 2001, "Características diferenciales de la financiación entre las pyme y las grandes empresas españolas. Asimetrías informativas, restricciones financieras y plazos de endeudamiento", Papeles de Economía Española, 89/90, 140-166.

Michaelas, N.; Chittenden, F. and Poutziouris, P., 1999, "Financial policy and capital structure choice in UK SMEs: empirical evidence from company panel data", Small Business Economics, 12, 113-130.

Miguel, A. de and Pindado, J., 2001, "Determinants of capital structure: new evidence from Spanish panel data", Journal of Corporate Finance, 7, 77-99.

Modigliani, F. and Miller, M. H., 1958, "The cost of capital, corporation finance and the theory of investment”, The American Economic Review, 68 (3), June, 261-297.

Modigliani, F. and Miller, M. H., 1963, "Corporate income taxes and the cost of capital: a correction", The American Economic Review, 53 (2), June, 433-443.

Myers, S. C., 1977, "Determinants of corporate borrowing”, Journal of Financial Economics, 5, $147-175$.

Myers, S. C., 1984, "The capital structure puzzle", The Journal of Finance, XXXIX (3), July, 575-592.

Myers, S. C. and Majluf, N. S., 1984, "Corporate financing and investment decisions when firms have information that investors do not have", Journal of Financial Economics, 13, $187-221$.

Norton, E., 1991, "Capital structure and small growth firms", The Journal of Small Business Finance, 1 (2), 161-177.

Ocaña, C.; Salas, V. and Vallés, J., 1994, "Un análisis empírico de la financiación de la pequeña y mediana empresa manufacturera española: 1983-1989", Moneda y Crédito, 199, 5796. 
Pettit, R. and Singer, R., 1985, "Small business finance: a research agenda", Financial Management, 14 (3), autumn, 47-60.

Rajan, R. G. and Zingales, L., 1995, "What do we know about capital structure? Some evidence from international data", The Journal of Finance, L (5), December, 1.421-1.460.

Saá-Requejo, J., 1996, "Financing Decisions: Lessons from the Spanish Experience”, Financial Management, 25 (3), autumn, 44-56.

Scott, J. H. Jr., 1976, "A theory of optimal capital structure”, The Bell Journal of Economics, 34 , spring, 33-54.

Scott, J. H. Jr., 1977, "Bankruptcy, secured debt, and optimal capital structure", The Journal of Finance, XXXII, March, 1-19.

Selva Domínguez, M. y Giner Manso, Y., 1999, "Incidencia del racionamiento del crédito en la estructura financiera de las PYMEs", Revista Europea de Dirección y Economía de la Empresa, 4 (4), 125-134.

Shyam - Sunder, L. and Myers, S. C., 1999, "Testing static tradeoff against pecking order models of capital structure", Journal of Financial Economics, 51, 219-244.

Titman, S. and Wessels, R., 1988, "The determinants of capital structure choice", The Journal of Finance, XLIII (1), March, 1-19.

Van der Wijst, D., 1989, "Financial structure in small business. Theory, tests and applications", Lecture notes in economics and mathematical systems, $\mathrm{n}^{\mathrm{o}} 320$, Springer - Verlag.

Van der Wijst, N. and Thurik, R., 1993, "Determinants of small firm debt ratios: an analysis of retail panel data", Small Business Economics, 5, 55-65.

Wagenvoort, R. and Hurst, C., 1999, "How well do European loan markets work?. Some insights from the financial structure of SMEs in three countries", EIB - Papers, 4 (2), 64-86.

Walker, David A., 1989a, "Financing the small firm", Small Business Economics, 1, fall, 285296.

Walker, David A., 1989b, "An empirical analysis of financing the small firm", in R. Yazdipour (ed.), 1991, Advances in Small Business Finance, Kluwer Academic Publishers, 47-61.

Warner, J. B., 1977, "Bankruptcy costs: some evidence", The Journal of Finance, XXXII (2), May, 337-347.

Zingales, L., 2000, "In search of new foundations", The Journal of Finance, LV (4), August, 1623-1653. 